\title{
PENGARUH MODEL LEARNING CYCLE 7E TERHADAP KEMAMPUAN BERPIKIR KRITIS PESERTA DIDIK
}

\author{
EFFECT OF LEARNING CYCLE MODEL 7E ON THE STUDENT CRITICAL THINKING SKILLS
}

\author{
Ahmad Ibnu Rusydi, Kosim, Hikmawati* \\ Program Studi Pendidikan Fisika, Jurusan Pendidikan MIPA, FKIP. Universitas Mataram \\ Jalan Majapahit No 62 Mataram, 83125, Indonesia \\ *Email: hikmawati@unram.ac.id
}

Diterima: 13 Juli 2018. Disetujui: 24 September 2018. Dipublikasikan: 29 September 2018

\begin{abstract}
Abstrak. Penelitian ini bertujuan untuk mengetahui pengaruh model siklus belajar 7E terhadap keterampilan berpikir kritis siswa SMAN 1 Gerung. Jenis penelitian adalah quasi eksperimental dengan desain penelitian post-test only control group design. Populasi penelitian adalah semua kelas X MIPA SMAN 1 Gerung, dengan teknik pengambilan sampel menggunakan purposive sampling dan diperoleh kelas X MIPA 3 sebagai kelas eksperimen dan kelas X MIPA 4 sebagai kelas kontrol. Pengumpulan teknik analisis data kritis berupa deskripsi dari 5 pertanyaan yang telah divalidasi dan dapat diandalkan. Berdasarkan hasil penelitian, ditemukan bahwa rata-rata post-test kemampuan berpikir kritis kelas eksperimen adalah 66,02 dan kelas kontrol adalah 52,80. Data yang diperoleh pertama diuji untuk normalitas dan homogenitas. Kedua kelas terdistribusi normal dan homogen, diikuti oleh pengujian hipotesis menggunakan uji statistik (t-test polled variance). Uji hipotesis pemikiran kritis dan $t_{\text {tabel }} 1,99656$ pada tingkat signifikan 0,05. Kesimpulan dari penelitian ini adalah ada pengaruh model 7E terhadap kemampuan berpikir kritis siswa SMA Gerung 1.
\end{abstract}

Kata Kunci: siklus belajar, keterampilan berpikir kritis

\begin{abstract}
This study aims to determine the effect of learning cycle model 7E on critical thinking skills of students of SMAN 1 Gerung. The research type is quasi experimental with post-test only control group design. Population is all class X MIPA SMAN 1 Gerung, with sampling technique using purposive sampling and obtained class X MIPA 3 as experiment class and class X MIPA 4 as control class. Data collection of critical thinking ability using the test technique in the form of a description of 5 questions that have been validated and reliable. Based on the result of research, it is found that the average post-test of critical thinking ability of experimental class is 66,02 and control class is 52,80. The obtained data were first tested for normality and homogeneity. Both classes were normally distributed and homogeneous, followed by hypothesis testing using statistical test (t-test polled variance). Test the hypothesis of critical thinking ability obtained $t$ count value of 4,0928 and $t$ table of 1.99656 at a significant level of 0.05 . In conclusion, there is influence of learning cycle model 7E to critical thinking ability of students of SMAN 1 Gerung.
\end{abstract}

Keyword: learning cycle, critical thinking skills

\section{PENDAHULUAN}

Perkembangan dunia yang begitu pesat mengharuskan sumber daya manusianya untuk memiliki beberapa keterampilan yang sesuai dengan tuntutan pada abad ke-21. Pemerintah sendiri telah melakukan tindakan dengan terus meningkatkan kurikulum yang ada untuk memenuhi tantangan tersebut.Sehingga berkembanglah suatu pembelajaran yang dinamakan pembelajaran abad ke-21. Dikutip dari Global Cities Education Network Report menginformasikan bahwa terdapat 5 keterampilan yang harus dimiliki oleh peserta didik pada abad ke21 yaitu, kreativitas serta inovasi, berpikir kritis (critical thinking), pemecahan masalah (problem solving), pengambilan keputusan (decision making), dan metakognisi [1]. Kemampuan berpikir kritis sendiri merupakan dasar yang sangat diperlukan bagi peserta didik untuk menyelesaikan berbagai persoalan yang diberikan oleh guru di sekolah. Terutama persoalan yang berhubungan dengan fisika.

Fisika merupakan bagian dari IPA yang pada hakikatnya merupakan kumpulan pengetahuan, cara berpikir, dan penyelidikan. Tantangan dalam mengajar fisika yaitu untuk menciptakan pengalaman yang melibatkan peserta didik dan memfasilitasi mereka agar dapat menguasai setiap materi yang diajarkan. Penyelenggaraan mata pelajaran fisika di SMA dimaksudkan sebagai wahana atau sarana untuk melatih para peserta didik agar dapat menguasai pengetahuan, konsep, dan prinsip fisika, memiliki kecakapan ilmiah, memiliki keterampilan proses sains dan keterampilan berpikir kritis dan kreatif [2]. Berdasarkan hakikat fisika, tersirat jelas bahwa yang diinginkan dalam pembelajaran fisika adalah peserta didik dituntut untuk melakukan suatu kegiatan ilmiah untuk menemukan pengetahuan serta memiliki sikap ilmiah.Pembelajaran fisika di sekolah menengah pada kenyataannya menunjukkan hal yang berlawanan 
dengan hakikat fisika itu sendiri. Proses pembelajaran yang dilaksanakan saat ini masih menggunakan paradigma lama yaitu pembelajaran yang berpusat pada guru (teacher-centered).

Terlihat di sekolah kebanyakan pembelajaran fisika cenderung bersifat informatif atau hanya berupa transfer pengetahuan dari guru ke peserta didik tanpa melibatkan kegiatan untuk menunjukkan mengapa pengetahuan tersebut penting untuk dipelajari. Peserta didik sangat sulit diajak untuk aktif dalam proses pembelajaran sehingga peserta didik beranggapan fisika hanya pelajaran yang sulit dan berisi rumusrumus serta teori, tanpa tahu bagaimana menerapkannya dalam kehidupan sehari-hari. Hal tersebut terjadi karena peserta didik kurang kesadaran dan antusiasme dalam mempelajari fisika. Padahal, pemahaman materi secara mendalam sangat penting dalam proses mengasah kemampuan berpikir kritis peserta didik terlebih dalam bidang fisika.

Berpikir kritis sangat berpengaruh pada dampak prestasi seorang peserta didik karena berpikir kritis menentukan aktif tidaknya peserta didik mengikuti semua kegiatan pembelajaran fisika. Guru harus membantu peserta didik untuk mengembangkan keterampilan berpikir kritis melalui beberapa metode dan model pembelajaran yang mendukung peserta didik untuk belajar secara aktif dan konstruktivis. Namun fakta dilapangan ternyata tidak demikian dari tahapan-tahapan pembelajaran yang dilakukan guru peserta didik kurang aktif untuk mengkonstruksi pengetahuannya sendiri. Berdasarkan hasil observasi yang sudah peneliti lakukan pada peserta didik kelas X MIPA di SMA Negeri 1 Gerung, terdapat beberapa masalah yang ditemukan pada saat proses pembelajaran. Banyak peserta didik yang tidak begitu memperhatikan penjelasan guru, mengganggu teman sebelahnya, dan ada pula yang mengantuk terutama yang duduk dipaling belakang. Hal ini terjadi karena kesadaran akan pentingnya belajar pada diri peserta didik kurang. Beberapa permasalahan tersebut berpengaruh terhadap hasil belajar peserta didik yang belum optimal.

Salah satu upaya yang dapat dilaksakan untuk membuat peserta didik lebih aktif adalah penggunaan model Learning Cycle 7E (Elicit, Engage, Explore, Explain, Elaborate, Evaluate, Extend). Learning cycle adalah salah satu model pembelajaran yang berbasis konstruktivisme.Teori konstruktivisme menyatakan bahwa ilmu pengetahuan tidak dapat ditransfer langsung dari guru ke peserta didik, melainkan dibangun secara aktif oleh peserta didik.Learning Cycle merupakan rangkaian tahap-tahap kegiatan yang diorganisir sedemikian rupa sehingga peserta belajar dapat menguasai sejumlah kompetensi yang harus dicapai dalam pembelajaran melalui peran aktif peserta didik.Rangkaian kegiatan dalam pembelajaran siklus ini dapat membantu peserta didik untuk membangun pengetahuan yang baru melalui interaksi dengan lingkungan. Model pembelajaran siklus 7E merupakan model pembelajaran yang mengintegrasikan keterampilan proses sains ke dalam sistem penyajian materi [3].

Kurangnya keaktifan pembelajaran dalam kelas dapat diatasi dengan pembelajaran yang memfasilitasi keterlibatan peserta didik, salah satu model pembelajaran yang memafsilitasi peserta didik yakni model learning cycle 7E. Hasil belajar peserta didik yang baik belum tentu selaras dengan kemampuan berpikir kritis peserta didik di dalam pembelajaran baik pula salah satu faktor penyebab kurang baiknya kemampuan berpikir kitis peserta didik adalah sifat pasif peserta didik selama proses pembelajaran.

Learning cycle adalah salah satu model pembelajaran yang berbasis konstruktivisme.Teori konstruktivisme menyatakan bahwa ilmu pengetahuan tidak dapat ditransfer langsung dari guru ke peserta didik, melainkan dibangun secara aktif oleh peserta didik."Learning cycle merupakan rangkaian tahaptahap kegiatan yang diorganisir sedemikian rupa sehingga peserta belajar dapat menguasai sejumlah kompetensi yang harus dicapai dalam pembelajaran melalui peran aktif peserta didik.Rangkaian kegiatan dalam pembelajaran siklus ini dapat membantu peserta didik untuk membangun pengetahuan yang baru melalui interaksi dengan lingkungan.Model pembelajaran ini pertama kali diperkenalkan oleh Robert Karplus dalam Science Curriculum Improvemenet Study/SCIS. Pada awalnya learning cycle memiliki tiga tahap, yaitu eksplorasi (exploration), pengenalan konsep (concept introduction), dan penerapan konsep (concept application). Tiga tahap siklus tersebut dikembangkan menjadi lima tahap yang terdiri atas tahap pembangkitan minat (engagement), eksplorasi (exploration), penjelasan (explanation), elaborasi (elaboration/extention), dan evaluasi (evaluation) atau disebut sebagai learning cycle 5E.

Eisenkraft mengembangkan kelima tahap tersebut di atas menjadi 7 tahap, yang dikenal dengan learning cycle 7E. Model pembelajaran siklus 7E merupakan model pembelajaran yang mengintegrasikan keterampilan proses sains ke dalam sistem penyajian materi. Perubahan siklus belajar $5 \mathrm{E}$ menjadi 7E terjadi pada fase Engage menjadi 2 tahapan yaitu Elicit dan Engage, serta pada fase Elaborate dan Evaluate menjadi 3 tahapan yaitu Elaborate, Evaluate, dan Extend" [3]. Mulai dari siklus 3E, setiap model siklus berikutnya merupakan perluasan dari model sebelumnya, misalnya $7 \mathrm{E}$ perubahan siklus belajar 5E menjadi $7 \mathrm{E}$ terjadi pada fase Engage menjadi 2 fase Elicit dan Engage, serta pada fase Elaborate dan Evaluate menjadi 3 fase yaitu Elaborate, Evaluate, dan Extend [4].

Model learning cycle 7E merupakan rangkaian tahap-tahap kegiatan (fase) yang diorganisasi sedemikian rupa sehingga peserta didik dapat menguasai kompetensi-kompetensi yang harus dicapai dalam pembelajaran dengan jalan berperan aktif. Model pembelajaran ini merupakan pendekatan yang ampuh untuk perancangan pembelajaran IPA yang 
aktif dan efektif karena memberikan suatu cara berfikir dan berperilaku yang konsisten dengan cara peserta didik belajar aktif. Model pembelajaran ini berbasis konstuktivistik yang berpusat pada peserta didik (student centered) serta dikembangkan sesuai dengan hakikat sains sebagai proses, produk dan sikap [5]. Pendekatan konstruktivis, pengetahuan dibangun oleh peserta didik melalui peran aktifnya selama proses pembelajaran dan peserta didik menggabungkan pengetahuan awal yang ada dengan pengetahuan baru. Model pembelajaran Learning Cycle $7 E$ merupakan model pembelajaran yang memberikan kesempatan kepada siswa untuk membangun pengetahuannya sendiri berdasarkan pada pengetahuan awal yang dimiliki [6-10].

Dari pendapat beberapa ahli di atas, peneliti menyimpulkan bahwa model pembelajaran learning cycle $7 E$ merupakan model pembelajaran student centered dengan mengadopsi prinsip konstruktivisme yang terdiri rangkaian tahap-tahap kegiatan (fase) yaitu tahap elicit, engage, explore, explain, elaborate, evaluate, extend, yang diorganisasi sedemikian rupa sehingga peserta didik dapat menguasai kompetensi yang harus dicapai dalam pembelajaran dengan jalan berperan aktif [11-13].

Menurut Eisenkraft [14] tahapan-tahapan model learning cycle 7Edapat dijelaskan sebagai berikut:

1. Elicit (Mendatangkan pengetahuan awal) Pada fase ini, guru berusaha menimbulkan atau mendatangkan pengetahuan awal peserta didik.Pada fase ini guru dapat mengetahui sampai dimana pengetahuan awal peserta didik terhadap pelajaran yang dipelajari dengan memberikan pertanyaanpertanyaan yang merangsang pengetahuan awal peserta didik agar timbul respon dari pemikiran peserta didik serta menimbulkan kepenasaran tentang jawaban dari pertanyaanpertanyaan yang diajukan oleh guru.Fase ini dimulai dengan pertanyaan mendasar yang berhubungan dengan pelajaran yang dipelajari dengan mengambil contoh yang mudah yang diketahui peserta didik seperti kejadian dalam kehidupan sehari-hari.

2. Engage(Pembangkitan Minat)

Fase digunakan untuk memfokuskan perhatian peserta didik, merangsang kemampuan berpikir serta membangkitkan minat dan motivasi peserta didik terhadap konsep yang diajarkan. Fase ini dapat dilakukan dengan demonstrasi, diskusi, membaca, atau aktivitas lain yang digunakan untuk membuka pengetahuan peserta didik dan mengembangkan rasa keigintahuan peserta didik.

3. Explore (menyelidiki)

Pada fase ini peserta didik memperoleh pengetahuan dengan pengalaman langsung yang berhubungan dengan konsep yang dipelajari.Peserta didik diberi kesempatan untuk bekerja dalam kelompok-kelompok kecil tanpa pengajaran langsung dari guru.Pada fase ini peserta didik diberi kesempatan untuk mengamati data, merekam data, mengisolasi variabel, merancang dan merencanakan eksperimen, membuat grafik, menafsirkan hasil, mengembangkan hipotesis serta mengatur temuan mereka. Guru merangkai pertanyaan, memberi masukan, dan menilai pemahaman.

4. Explain (menjelaskan)

Pada fase ini peserta didik diperkenalkan pada konsep, hukum dan teori baru. Peserta didik menyimpulkan dan mengemukakan hasil dari temuannya pada fase explore. Guru mengenalkan peserta didik pada beberapa kosa kata ilmiah, dan memberikanpertanyaan untuk merangsang peserta didik agar menggunakan istilah ilmiah untuk menjelaskan hasil eksplorasi.

5. Elaborate (menerapkan)

Fase yang bertujuan untuk membawa peserta didik menerapkan simbol, definisi, konsep, dan keterampilan pada permasalahan yang berkaitan dengan contoh dari pelajaran yang dipelajari.

6. Evaluate (evaluasi)

Fase evaluasi model pembelajaran learning cycle 7Eterdiri dari evaluasi formatif dan evaluasi sumatif.Evaluasi formatif tidak boleh dibatasi pada siklus-siklus tertentu saja, sebaiknya guru selalu menilai semua kegiatan peserta didik.

7. Extend (memperluas)

Pada tahap ini bertujuan untuk berfikir, mencari menemukan dan menjelaskan contoh penerapan konsep yang telah dipelajari bahkan kegiatan ini dapat merangsang peserta didik untuk mencari hubungan konsep yang mereka pelajari dengan konsep lain yang sudah atau belum mereka pelajari.

\section{METODE PENELITIAN}

Jenis penelitian yang digunakan adalah penelitian jenis quasi experimental (eksperimen semu). Menurut Setyosari [15] penelitian jenis quasi experimental merupakan suatu cara untuk menguji hubungan sebab-akibat, di mana peneliti memberikan perlakuan kepada subjek untuk menentukan apakah perlakuan tersebut memiliki dampak atau pengaruh terhadap variabel atau faktor hasil tertentu.

Variabel penelitian adalah suatu atribut atau sifat atau nilai dari orang, obyek atau kegiatan yang mempunyai variasi tertentu yang ditetapkan oleh peneliti untuk dipelajari dan kemudian ditarik kesimpulannya. Dalam suatu penelitian, terdapat tiga variabel yang biasanya akan dipelajari dan ditarik kesimpulannya. Ketiga variabel tersebut adalah variabel bebas, variabel terikat, dan variabel control [16]. Variabel bebas dalam penelitian ini adalah model learning cycle 7E. Dalam penelitian ini, variabel terikatnya adalah kemampuan berpikir kritis peserta didik. Variabel kontrol di dalam penelitian ini berupa pengetahuan awal kelas ekperimen dan kelas kontrol, guru, materi, tujuan pembelajaran, instrumen yang digunakan, dan cara penilaian.

Rancangan penelitian yang digunakan dalam penelitian ini adalahposttest only control group design. Dalam rancangan penelitian ini, dipilih dua 
kelas sebagai sampel, yakni satu kelas sebagai kelas kontrol dan satu kelas lainnya sebagai kelas eksperimen.Kelas kontrol diberikan perlakuan berupa model pembelajaran konvensional, sedangkan pada kelas eksperimen diberikan perlakuan berupa model learning cycle 7E. Peserta didik pada kedua kelas tersebut diberikan tes akhir untuk mengetahui kemampuan berpikir kritis peserta didik setelah diberikan perlakuan tersebut. Tabel 1 berikut ini memberikan gambaran desain penelitian yang dilaksanakan.

Tabel 1 Desain Penelitian

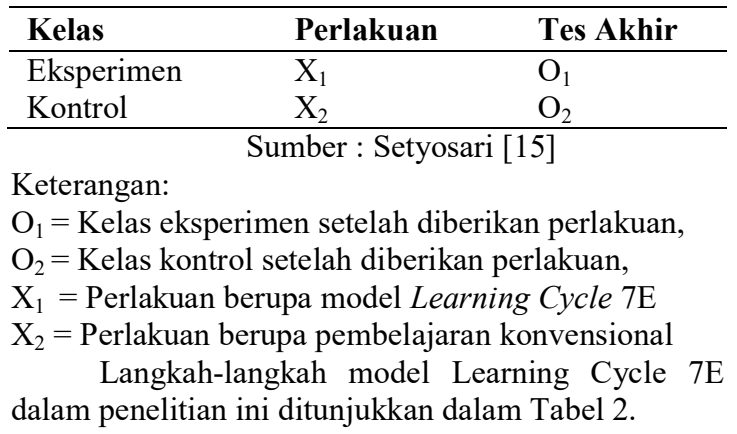

Tabel 2 Model Learning Cycle 7E

\begin{tabular}{ll}
\hline Fase & Arah Pembelajaran \\
\hline Elicit & $\begin{array}{l}\text { Memfokuskan perhatian peserta didik } \\
\text { Menyelidiki pengetahuan awal yang } \\
\text { telah dimiliki peserta didik }\end{array}$ \\
\hline Engage & \begin{tabular}{l} 
Kegiatan pada fase ini adalah \\
memusatkan perhatian peserta \\
didik dengan kegiatandemonstrasi, \\
diskusi, membaca, atau aktivitas lain \\
yang digunakan untuk membuka \\
pengetahuan peserta didik dan \\
mengembangkan rasa keingintahuan \\
peserta didik. \\
Bertukar informasi dan pengalaman \\
\hline Kegiatan pada fase ini adalah \\
memberikan waktu kepada peserta didik \\
untuk mengkonstruksi pengetahuannya \\
dengan melaksanakan sebanyak \\
mungkin bekerja sama dengan \\
kelompoknya untuk menjawab \\
pertanyaan.
\end{tabular} \\
\hline Kegiatan pada fase ini adalah memberi \\
kesempatan kepada peserta didik untuk \\
memberikan analisis dan penjelasan.
\end{tabular}

\begin{tabular}{|c|c|}
\hline $\begin{array}{l}\text { Fase } \\
\text { LC7E }\end{array}$ & Arah Pembelajaran \\
\hline & memahami konsep. \\
\hline Extend & $\begin{array}{l}\text { Kegiatan pada fase yang terakhir ini } \\
\text { adalah refleksi dengan membuat } \\
\text { rangkuman, kesimpulan } \\
\text { mengembangkan aplikasi konsep dalam } \\
\text { kehidupan nyata yang lebih kompleks. }\end{array}$ \\
\hline
\end{tabular}

Tabel 3 Indikator Kemampuan Berpikir Kritis

\begin{tabular}{|c|c|c|}
\hline Indikator & $\begin{array}{l}\text { Sub } \\
\text { Indikator }\end{array}$ & Deskriptor \\
\hline $\begin{array}{l}\text { Klarifikasi } \\
\text { dasar }\end{array}$ & $\begin{array}{l}\text { Memfokus } \\
\text { kan } \\
\text { Pertanyaan }\end{array}$ & $\begin{array}{l}\text { Mengidentifikasi atau } \\
\text { merumuskan kriteria } \\
\text { dan mempertimbangkan } \\
\text { jawaban yang mungkin }\end{array}$ \\
\hline $\begin{array}{l}\text { Keputusan } \\
\text { dasar }\end{array}$ & $\begin{array}{l}\text { Mempertim } \\
\text { bangkan } \\
\text { kredibilitas } \\
\text { sumber }\end{array}$ & $\begin{array}{l}\text { Kemampuan } \\
\text { memberikan alasan }\end{array}$ \\
\hline Inferensi & $\begin{array}{l}\text { Membuat } \\
\text { inferensi } \\
\text { materi }\end{array}$ & $\begin{array}{l}\text { Menjelaskan hipotesis } \\
\text { karakteristik aktivitas } \\
\text { menyelidiki terdiri atas } \\
\text { dua hal: } \\
\text { Mencari fakta-fakta dan } \\
\text { mencari penjelasan } \\
\text { kemungkinan lainnya }\end{array}$ \\
\hline $\begin{array}{l}\text { Penjelasan } \\
\text { lebih } \\
\text { lanjut }\end{array}$ & $\begin{array}{l}\text { Mengidenti } \\
\text { fikasi } \\
\text { asumsi- } \\
\text { asumsi }\end{array}$ & $\begin{array}{l}\text { Perkiraan } \\
\text { (membutuhkan saran } \\
\text { untuk membuat } \\
\text { pendirian) } \\
\text { Membutuhkan asumsi- } \\
\text { asumsi (untuk alasan } \\
\text { yang lebih kuat) } \\
\text { Menggunakan asumsi- } \\
\text { asumsi untuk menilai } \\
\text { hipotesis }\end{array}$ \\
\hline Menalar & Menalar & $\begin{array}{l}\text { Mempertimbangkan } \\
\text { dan memberi alasan } \\
\text { dari pendapat-pendapat, } \\
\text { alasan-alasan, asumsi- } \\
\text { asumsi, dan saran } \\
\text { lainnya yang mereka } \\
\text { tidak setujui atau yang } \\
\text { meragukan "pemikiran } \\
\text { pengandaian" }\end{array}$ \\
\hline
\end{tabular}

Penelitian ini dilaksanakan mulai dari penetapan judul pada bulan Oktober 2017 sampai dengan pengumpulan laporan penelitian pada bulan Juli 2018.Penelitian ini dilaksanakan di SMA Negeri 1 Gerung.Populasi adalah keseluruhan kelompok dari mana sampel-sampel diambil. Dalam penelitian ini yang menjadi populasi adalah seluruh peserta didik kelas X MIPA SMAN 1 Gerung yang berjumlah 198 peserta didik yang terbagi ke dalam 6 kelas. Teknik pengambilan sampel menggunakan teknik purposive sampling, karena pengambilan anggota sampel dipilih oleh peneliti dengan pertimbangan tertentu. Penelitian ini dilakukan dalam 3 tahap, yaitu tahap perencanaan, 
tahap pelaksanaan, dan tahap penyelesaian.Dalam penelitian ini, instrumen yang digunakan untuk mengukur kemampuan berpikir kritis peserta didik adalah instrumen tes. Instrumen tes tersebut berupa soal isian sebanyak 5 buah untuk mengukur kemampuan berpikir kritis peserta didik.

Instrumen yang digunakan dalam penelitian ini adalah instrumen berupa tes.Uji coba instrumen dilakukan terhadap tes uraian yang digunakan.Uji coba ini bertujuan untuk mengetahui apakah tes yang digunakan dapat dikatakan baik atau tidak. Oleh karena itu, perlu dilakukan analisis butir soal yang meliputi:Uji Validitas, Uji Reliabilitas, Uji Tingkat Kesukaran Soal, Uji Daya Beda Soal.

Data dalam penelitian ini berupa kemampuan berpikir kritis peserta didik.Pengumpulan data dalam penelitian ini dilakukan dengan metode tes berbentuk uraian 5 soal untuk mengukur kemampuan berpikir kritis peserta didik.Pemberian tes dilakukan pada tes akhir (post-test). Tes akhir ini dimaksudkan untuk mengetahui kemampuan berpikir kritis peserta didik setelah proses pembelajaran menggunakan model learning cycle 7E. Sumber data dalam penelitian ini adalah nilai semua peserta didik kelas eksperimen dan kelas kontrol.

Data yang diambil dari kedua kelas berupa data akhir sesuai dengan desain penelitian yang digunakan.Data akhir kemudian dianalisis dengan menggunakan uji normalitas, uji homogenitas, dan uji hipotesis.

\section{HASIL DAN PEMBAHASAN}

Uji instrumen penelitian ini dilakukan pada kelas XI MIPA 7 SMAN 1 Gerung yang telah memperoleh materi getaran harmonis ini sebelumnya.Tes kemampuan berpikir kritis yang diujikan sebanyak 5 item soal uraian dan tiap item soal mewakili satu indikator berpikir kritis. Tes uraian kemampuan berpikir kritis dianalisis validitas, reliabilitas, taraf kesukaran, dan daya beda soal sebelum digunakan untuk postest.

Nilai $r_{x y}$ untuk semua item soal kemampuan berpikir kritis lebih besar dibandingkan dengan nilai $\mathrm{r}_{\text {tabel}}$, sehingga dapat disimpulkan bahwa semua item soal termasuk dalam kategori valid dan layak digunakan untuk postest. Nilai $\mathrm{r}_{11}$ untuk semua item soal kemampuan berpikir kritis lebih besar dibandingkan dengan nilai $r_{\text {tabel }}$, sehingga dapat disimpulkan bahwa semua item soal termasuk kategori reliabel dan layak digunakan untuk postest.

Berdasarkan hasil analisis tingkat kesukaran soal kemampuan berpikir kritis, diketahui bahwa satu soal termasuk dalam kategori mudah yaiu item soal nomer 1, tiga soal termasuk dalam kategori sedang yaitu item soal nomer 2, 3, dan 5, serta soal nomer 4 termasuk dalam kategori sukar atau sulit. Berdasarkan hasil analisis daya beda soal diketahui empat item soal memiliki daya beda yang termasuk dalam kategori cukup dan satu item soal memilik daya beda jelek. Dengan demikian, diperoleh kesimpulan bahwa kelima item soal dapat digunakan untuk posttest, karena sudah memenuhi syarat instrumen yaitu instrumen harus valid dan reliabel.

Data kemampuan akhir yang diperoleh pada penelitian ini adalah data setelah diberikan perlakuan.Tes akhir diberikan untuk mengetahui homogenitas, normalitas, dan hipotesis penelitian. Adapun hasil tes akhir dapat dilihat pada Tabel 4.

Tabel 4 Hasil Tes Akhir

\begin{tabular}{lllll}
\hline Kelas & $\begin{array}{l}\text { Jumlah } \\
\text { Peserta } \\
\text { Didik }\end{array}$ & $\begin{array}{l}\text { Nilai } \\
\text { Tertinggi }\end{array}$ & $\begin{array}{l}\text { Nilai } \\
\text { Terendah }\end{array}$ & $\begin{array}{l}\text { Rata- } \\
\text { rata }\end{array}$ \\
\hline Eksperimen & 34 & 85 & 30 & 66,02 \\
\hline Kontrol & 34 & 75 & 25 & 52.80 \\
\hline
\end{tabular}

Tabel 4 terlihat bahwa nilai tertinggi pada kelas eksperimen adalah 85 dan kelas kontrol adalah 75 , sedangkan nilai terendah pada kelas eksperimen adalah 30 dan kelas kontrol adalah 25. Rata-rata nilai kelas eksperimen dan kelas kontrol berturut-turut sebesar 66,02 dan 52.80 .

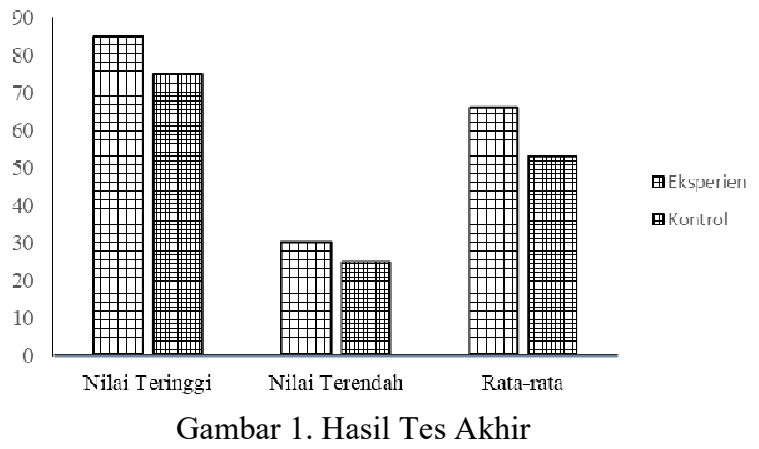

Gambar 1 menunjukan bahwa hasil tes akhir pada kelas eksperimen lebih baik dibandingkan dengan kelas kontrol dari segi nilai tertinggi, nilai terendah, dan nilai rata-rata.

Hasil uji homogenitas yang dapat dilihat pada Tabel 5, dan didapatkan bahwa hasil Post-test menunjukkan bahwa $F_{\text {hitung }}<F_{\text {tabel }}$ pada taraf signifikansi $5 \%$.

Uji normalitas dilakukan untuk mengetahui data yang digunakan terdistribusi normal atau tidak.Hasil uji normalitas dapat dilihat pada Tabel 6.Uji normalitas Post-test yang dilakukan dengan taraf signifikansi $5 \%$, diketahui bahwa $\chi_{\text {hitung }}^{2}<\chi_{\text {tabel }}^{2}$ sehingga data terdistribusi normal.

Setelah dilakukan uji homogenitas dan uji normalitas maka selanjutnya menguji hipotesis guna menentukan hipotesis penelitian. Uji hipotesis yang dilakukan dengan mengolah hasil data tes akhir kemampuan berpikir kritis peserta didik diperoleh data seperti Tabel 7. 
Tabel 5 Hasil Uji Homogenitas

\begin{tabular}{|c|c|c|c|c|c|}
\hline Kelas & $\bar{X}$ & $\mathrm{~S}^{2}$ & $\mathbf{F}_{\text {hitung }}$ & $F_{\text {tabel }}$ & Keterangan \\
\hline Eksperimen & 66.02 & 207.70 & \multirow{2}{*}{1.410} & \multirow{2}{*}{1.72} & \multirow{2}{*}{ Homogen } \\
\hline Kontrol & 52.80 & 147.25 & & & \\
\hline
\end{tabular}

Tabel 6 Hasil Uji Normalitas

\begin{tabular}{cccc}
\hline Kelas & $\chi_{\text {hitung }}^{2}$ & $\chi_{\text {tabel }}^{2}$ & Kriteria \\
\cline { 1 - 2 } Eksperimen & 8.880891 & \multirow{2}{*}{12.592} & $\begin{array}{c}\text { Terdistribusi } \\
\text { Normal }\end{array}$ \\
\cline { 1 - 2 } Kontrol & 7.803666 & &
\end{tabular}

Tabel 7 Hasil Uji Hipotesis

\begin{tabular}{ccccc} 
Kelas & $\begin{array}{c}\text { Standar } \\
\text { Deviasi } \\
(\mathbf{s})\end{array}$ & $\begin{array}{c}\text { Varian } \\
\mathbf{s ~ ( \mathbf { s } ^ { 2 } )}\end{array}$ & $\mathbf{t}_{\text {hitung }}$ & $\mathbf{t}_{\text {Tabel }}$ \\
\hline Eksperimen & 14.41 & 207.70 & 4.0928 & 1.99254 \\
Kontrol & 12.13 & 147.25 & & \\
\hline
\end{tabular}

Berdasarkan Tabel 7, diperoleh $t_{\text {hitung }}=$ 4.0928 sedangkan $t_{\text {tabel }}=1.99254$. Hal ini menunjukkan bahwa $t_{\text {hitung lebih besar dari pada }}$ $\mathrm{t}_{\text {tabel }}$ dengan demikian $\mathbf{H}_{\mathbf{0}}$ ditolak dan $\mathbf{H}_{\mathbf{a}}$ diterima, artinya ada Pengaruh Model Learning Cycle 7E (Elicit, Engage, Explore, Explain, Elaborate, Evaluate, Extend) Terhadap Kemampuan Berpikir Kritis Peserta Didik SMA N 1 Gerung.

Tahapan model Learning cycle 7E menuntun peserta didik untuk berpikir secara aktif dalam proses pembelajaranya. Peserta didik dituntun dalam mencari konsep, memahami, hingga mengaplikasikan konsep tersebut ke dalam kehidupan sehari-hari. Proses keterlibatan peserta didik berpikir secara aktif dalam pembelajaran akan merangsang kemampuan berpikir kritisnya. Kemampuan berpiki kritis peserta didik dapat dimunculkan di setiap tahapan model Learning cycle 7E.

Tahap perama yakni mengetahui pengetahuan awal (Elicit) Pada tahap ini guru dapat mengetahui sampai dimana pengetahuan awal peserta didik terhadap pelajaran yang akan dipelajari dengan memberikan pertanyaanpertanyaan yang merangsang pengetahuan awal peserta didik agar timbul respon dari pemikiran peserta didik serta menimbulkan kepenasaran tentang jawaban dari pertanyaan yang diajukan oleh guru. Tahap ini melatih peserta didik mempertimbangkan jawaban dari pertanyaan yang diberikan.

Tahap kedua yaitu pembangkitan minat (Engage), dalam tahap ini guru memberikan demonstrasi dan memunculkan pertanyaan kemudian memperoleh respon dari peserta didik sehingga terjadi diskusi mendalam dengan peserta didik.Tahap ini/ melatih peseta didik memberikan alasan dari jawaban pertanyaan yang diberikan.

Tahap ketiga eksplorasi (eksplore)dalam tahap ini peserta didik harus aktif menggali pengetahuannya sendiri melalui eksperimen karena guru hanya sebagai fasilitator dan menumbuhkan motivasi peserta didik.Kemampuan berpikir kritis yang dapat dimunculkan dalam tahap ini yaitu pada awal kegiatan sebelum praktikum dimulai, peserta didik dituntut untuk membuat rumusan masalah serta merumuskan hipotesis di LKPD dengan dibimbing oleh guru.Membuat rumusan masalah dan merumuskan hipotesis merupakan salah satu bagian dari kemampuan berpikir kritis.

Tahap keempat penjelasan (Explain) dalam tahap ini peserta didik menjelaskan konsep yang dibahas dengan kata-kata dan pemikiran peserta didik sendiri dan mengklarifikasi penjelasannya.Tahap ini memunculkan kemampuan berpikir kritis peserta didik yaitu menjelaskan mengenai materi yang telah mereka pahami dengan memberikan klarifikasi berupa fakta dan data yang relevan.

Tahap kelima elaborasi (elaborate) dalam tahap ini peserta didik menerapkan konsep atau keterampilan pada situasi baru. Kemampuan berpikir kritis yang dapat dimunculkan dalam tahap elaborasi adalah melatih peserta didik untuk menerapkan konsep yang dipahami terhadap sebuah situasi nyata.

Tahap keenam evaluasi (evaluate) dalam tahap ini yang dilakukan adalah mengevaluasi pada seluruh pengalaman dari setiap tahapan model Learning cycle 7E.Kemampuan berpikir kritis yang 
dapat dimunculkan dalam tahap ini yaitu kemampuan berpikir dalam membuat kesimpulan.

Tahap ketujuh memperluas (extend) pada tahap ini bertujuan untuk berfikir, mencari menemukan dan menjelaskan contoh penerapan konsep yang telah dipelajari bahkan kegiatan ini dapat merangsang peserta didik untuk mencari hubungan konsep yang mereka pelajari dengan konsep lain yang sudah atau belum mereka pelajari. seluruh pengalaman dari setiap tahapan model Learning cycle $7 \mathrm{E}$ juga melatih kemampuan peserta didik untuk menalar karena disetiap tahapnya peserta didik harus berpikir dan berperan aktif selama proses pembelajaran.

Aspek-aspek kemampuan berpikir kritis yang harus dicapai peserta didik lebih banyak diaplikasikan dalam penerapan model learning cycle 7E dimana pada metode pecobaannya menggunakan LKPD khusus model learning cycle $7 \mathrm{E}$ yang isi LKPD sesuai dengan sintaks model learning cycle 7E yang membantu melatih kemampuan berpikir kritis peserta didik karena melibatkan peserta didik secara optimal dalam proses pembelajaran sehingga peserta didik aktif mendapatkan pengetahuannya melalui serangkaian kegiatan learning cycle $7 \mathrm{E}$ berbasis percobaan.

Hal tersebut di atas sesuai dengan apa yang dikemukakan oleh Snyder dan Snyder [16], lingkungan belajar yang melibatkan peserta didik aktif dalam penyelidikan (penelitian) suatu informasi dan mengaplikasikan pengetahuan mereka meningkatkan kemampuan berpikir kritis peserta didik dibandingkan dengan model pembelajaran konvensional yang menggunakan LKPD biasa yang kurang mengaktifkan peserta didik selama proses pembelajaran dan saat percobaan. Hal ini sesuai nilai rata-rata kemampuan berpikir kritis pada kelas eksperimen dan kelas kontrol setelah diberikan perlakuan. Kemampuan berpikir kritis pada kelas eksperimen sebesar 66.02 berkategori lebih kritis daripada kelas kontrol sebesar 52.80.

Perbedaan kemampuan berpikir kritis pada kedua kelas mengindikasikan bahwa model pembelajaran yang diterapkan pada kelas eksperimen memberikan berpengaruh yang lebih baik daripada kelas kontrol. Untuk mengetahui adanya pengaruh model learning cycle 7E terhadap kemampuan berpikir kritis peserta didik maka diperlukan uji lanjut dengan uji hipotesis menggunakan uji-t dua pihak. Hasil perhitungan uji-t dua pihak menunjukkan bahwa nilai $t_{\text {hitung }}>$ $t_{\text {tabel }}$. Berdasarkan kriteria bahwa jika $t_{\text {hitung }}>$ $t_{\text {tabel }}$, menunjukkan adanya pengaruh model learning cycle 7E terhadap kemampuan berpikir kritis peserta didik SMAN 1 gerung. Hal ini sesuai dengan penelitian yang dilakukan oleh Hardiansyah [2] bahwa penggunaan model learning cycle 7E berpengaruh terhadap kemampuan berpikir kritis peserta didik.
Penelitian Septiana [18] menyatakan bahwa menggunakan model learning cycle 5Eberbasis eksperimen dapat lebih mengembangkan kemampuan berpikir kritis peserta didik daripada menggunakan menggunakan model pembelajaran konvensional. Begitu pula hasil penelitian yang dilakukan oleh Hikmawati [19] yang mengatakan model learning cycle memiliki pengaruh terhadap kecapakan hidup peserta didik dalam hal ini kemampuan berpikir kritis.Hal ini menunjukkan bahwa penerapan model pembelajaran learning cycle 7E berpengaruh terhadap kemampuan berpikir kritis peserta didik.

Berdasarkan rangkaian pembelajaran yang diterapkan pada kelas eksperimen yang menunjukkan adanya proses untuk melatih kemampuan berpikir kritis karena kemampuan berpikir kritis tidak akan berkembang apabila tidak dilatih dan memerlukan waktu dan kesabaran guru dalam membimbing. Seperti yang dikemukakan oleh Snyder dan Snyder [16] kemampuan berpikir kritis membutuhkan latihan, praktik, dan kesabaran. Kegiatan-kegiatan dalam model learning cycle $7 \mathrm{E}$ merupakan sarana yang lebih tepat dan efektif dalam pencapaian indikatorindikator kemampuan berpikir kritis, sehingga dapat disimpulkan bahwa dengan menggunakan model learning cycle 7E dapat lebih mengembangkan kemampuan berpikir kritis peserta didik daripada menggunakan model pembelajaran konvensional.

\section{KESIMPULAN}

Berdasarkan rumusan masalah, hasil penelitian, dan pembahasan dapat disimpulkan bahwa: Ada pengaruh model learning cycle 7E terhadap kemampuan berpikir kritis peserta didik SMAN 1 Gerung. Adapun saran-saran yang dapat diberikan yaitu: Model learning cycle 7E dapat menjadi alternatif model pembelajaran yang dapat diterapkan oleh guru untuk melatih kemampuan berpikir tingkat tinggi peserta didik dalam mengajarkan fisika. Penelitian ini dapat digunakan sebagai referensi dan perbandingan jika pembaca ingin memperluas penelitian ini sehingga dapat memperkuat hasil penelitian.

\section{DAFTAR PUSTAKA}

[1] Tamami, F, Rokhmat, J, dan Gunada, I.W. 2017. Penerapan Pendekatan Berpikir Kausalitik Scaffolding Tipe 2A Modifikasi Berbantuan LKS Terhadap Kemampuan Pemecahan Masalah Optik Geometri dan Kreativitas Siswa Kelas XI SMAN 1 Mataram.Jurnal Pendidikan Fisika dan Teknologi. Vol. 3, No. 1: 76-83.

[2] Hardiansyah, D, Waslaluddin, dan Rusnayati, H. 2013.Penerapan Model Pembelajaran Learning Cycle 7E untuk 
Meningkatkan Keterampilan Berpikir Kritis dan Penguasaan Konsep Siswa SMA.Jurnal Pengajaran Fisika Sekolah Menengah. Vol. 5, No. 1: 27-33.

[3] Apriyani, S.A dan Suprapto, K.A. 2013.Penerapan model 7E (Elicit, Engage, Explore, Explain, Elaborated/Extend, and Evaluate) Learning Cycle Pada Pelajaran Fisika dalam Implementasi Kurikulum 2013: 67-70.

[4] Balta, N dan Sarac, H. 2016. The Effect of 7E Learning Cycle on Learning in Science Teaching: A metaAnalysis Study. European Journal of Educational Research. Vol. 5, Issue 2:61-72

[5] Al-idrus, S. Q. M. J., Hikmawati, H., \& Wahyudi, W. (2015). Pengaruh model pembelajaran berbasis masalah berbantuan video kartun terhadap hasil belajar fisika siswa kelas xi sman 1 sikur tahun ajaran 2014/2015. Jurnal Pijar MIPA, 10(1).

[6] Suciati, N.N.A, Arnyana, I.B.P, dan Setiawan, I.G.A.N. 2014. Pengaruh Model Pembelajaran Siklus Belajar Hipotetik Deduktif Dengan Setting 7E Terhadap Hasil Belajar IPA Ditinjua Dari Sikap Ilmiah Siswa SMP. e-Journal Program Pascasarjana Universitas Pendidikan Ganesha. 4, 1.

[7] Sulastri, E, Hikmawati, dan Gunada, I.W. 2018.Pengaruh Model Learning Cycle $7 E$ Terhadap Hasil BelajarFisika Siswa Kelas XI Sman 8 Mataram.Jurnal Pendidikan Fisika dan Teknologi.Vol. 4, No 1: 56-65.

[8] Sutrisno, W, Dwiastuti, S, dan Karyanto, P. 2012. Pengaruh Model Learning Cycle $7 E$ Terhadap Motivasi Belajar Siswa Dalam Pembelajaran Biologi.Seminar Nasional IX Pendidikan Biologi FKIP UNS: 185-189

[9] Latifa, B.R.A, Verawati, N.N.S.P, dan Harjono, A. 2017. Pengaruh Model Learning Cycle 5E (Engage, Explore, Explain,Elaboration, \& Evaluate) Terhadap Kemampuan BerpikirKritis Peserta Didik Kelas X MAN 1 Mataram.Jurnal Pendidikan Fisika dan Teknologi. Vol. 3, No. 1: 61-67.

[10] Suryani, A. I., Jufri, A. W., \& Setiadi, D. (2017). Pengaruh Model Pembelajaran 5e Terintegrasi Pendekatan Saintifik Terhadap Kemampuan Literasi Sains Siswa SMPN 1 Kuripan Tahun Ajaran 2016/2017. Jurnal Pijar Mipa, 12(1).

[11] Patmah, P., Purwoko, A. A., \& Muntari, M. Pengaruh Model Pembelajaran Learning Cycle 7e terhadap Hasil Belajar Kimia Ditinjau dari Kemampuan Berpikir Kritis Siswa. Jurnal Penelitian Pendidikan IPA, 3(2).
[12] Suryani, A. I., Jufri, A. W., \& Setiadi, D. (2017). Pengaruh Model Pembelajaran 5E Terintegrasi Pendekatan Saintifik Terhadap Kemampuan Literasi Sains Siswa SMPN 1 Kuripan Tahun Ajaran 2016/2017. Jurnal Pijar Mipa, 12(1).

[13] Purwoko, A. A. (2017). Pengaruh Model Pembelajaran Learning Cycle 7E Terhadap Hasil Belajar Kimia Ditinjau Dari Kemampuan Berpikir Kritis Siswa. Jurnal Penelitian Pendidikan IPA, 3(2).

[14] Eisenkraft, A. 2003. Expanding the $5 \mathrm{E}$ Model A purposed $7 \mathrm{E}$ model emphasizes "transfer of learning" and theimportance of eliciting prior understanding. Published by the National Science Teachers Association, 1840 Wilson Blvd., Arlington, VA 222013000 .

[15] Setyosari, P. 2013. Metode Penelitian Pendidikan \& Pengembangan. Jakarta: Kencana

[16] Sugiyono. 2011. Statistika untuk Penelitian. Bandung: Alfabeta.

[17] Snyder, L. G. dan Snyder, M. J. 2008.Teaching Critical Thinking and Problem Solving Skills.The Delta Pi Epsilon Journal, 2, Spring/Summer.

[18] Septiana, I.S, Hikmawati, dan Harjono A. 2018. Pengaruh Model Learning Cycle $5 E$ Berbasis Eksperimen Terhadap Kemampuan BerpikirKritis Fisika Peserta Didik Kelas XI SMAN 1 Gerung.Jurnal Pendidikan Fisika dan Teknologi. 4, 1, 61-67.

[19] Hikmawati dan Rokhmat, J. 2017.The Implementation Of Learning Devices With Scientific Approach To Improve Student Life Skills.Jurnal Pendidikan Fisika Indonesia.Vol. 13, No. 1: 1-8. 